\title{
Are leaf physiological traits related to leaf water isotopic enrichment in restinga woody species?
}

\author{
BRUNO H.P. ROSADO ${ }^{1,3}$, EDUARDO A. DE MATTOS ${ }^{1}$ and LEONEL DA S.L. STERNBERG ${ }^{2}$ \\ ${ }^{1}$ Departamento de Ecologia, IB, CCS, Universidade Federal do Rio de Janeiro, \\ Av. Brigadeiro Trompowski, s/n, C.P. 68020, 21941-970 Rio de Janeiro, RJ, Brasil \\ ${ }^{2}$ Department of Biology, University of Miami, Coral Gables, FL 33124, USA \\ ${ }^{3}$ Departamento de Ecologia, Instituto de Biologia Roberto Alcântara Gomes, Universidade do Estado do Rio de Janeiro, \\ Rua São Francisco Xavier, 524, Maracanã, 20550-019 Rio de Janeiro, RJ, Brasil
}

Manuscript received on March 23, 2012; accepted for publication on August 23, 2012

\begin{abstract}
During plant-transpiration, water molecules having the lighter stable isotopes of oxygen and hydrogen evaporate and diffuse at a faster rate through the stomata than molecules having the heavier isotopes, which cause isotopic enrichment of leaf water. Although previous models have assumed that leaf water is well-mixed and isotopically uniform, non-uniform stomatal closure, promoting different enrichments between cells, and different pools of water within leaves, due to morpho-physiological traits, might lead to inaccuracies in isotopic models predicting leaf water enrichment. We evaluate the role of leaf morphophysiological traits on leaf water isotopic enrichment in woody species occurring in a coastal vegetation of Brazil known as restinga. Hydrogen and oxygen stable isotope values of soil, plant stem and leaf water and leaf traits were measured in six species from restinga vegetation during a drought and a wet period. Leaf water isotopic enrichment relative to stem water was more homogeneous among species during the drought in contrast to the wet period suggesting convergent responses to deal to temporal heterogeneity in water availability. Average leaf water isotopic enrichment relative to stem water during the drought period was highly correlated with relative apoplastic water content. We discuss this observation in the context of current models of leaf water isotopic enrichment as a function of the Péclet effect. We suggest that future studies should include relative apoplastic water content in isotopic models.
\end{abstract}

Key words: leaf water isotopic enrichment, Péclet effect, restinga, leaf morpho-physiological traits.

\section{INTRODUCTION}

Water molecules having the lighter isotopes of hydrogen or oxygen $\left({ }^{16} \mathrm{O}\right.$ and $\left.{ }^{1} \mathrm{H}\right)$ will evaporate and diffuse at a faster rate through the stomata than those having the heavier isotopes $\left({ }^{18} \mathrm{O}\right.$ and $\left.{ }^{2} \mathrm{H}\right)$, which will cause isotopic enrichment of leaf water. Many studies have indicated that this isotopic

Correspondence to: Bruno Henrique Pimentel Rosado

E-mail: brunorosado@gmail.com enrichment can be indicative of the relative humidity during the transpiration flux (Flanagan 1993, Roden and Ehleringer 1999). It can also be used to identify isotope composition in plant cellulose for environmental reconstructions via tree-ring cellulose (Roden and Ehleringer 2000). Additionally, the understanding of the causes of leaf water isotopic enrichment is an useful tool to parameterize models, based on plant responses, i.e., 
to predict the gas exchanges between biosphereatmosphere in different scales (Yakir and Sternberg 2000, Lai et al. 2008).

The model developed by Craig and Gordon (1965) predicts that isotopic enrichment is mainly driven by climate and that there are two isotope effects during evaporation: an equilibrium effect that occurs during isotope exchange reactions converting water from liquid to vapor; and a kinetic effect promoted by distinct mass-dependent diffusion rates (Flanagan et al. 1991, Dawson et al. 2002). A good fit has been observed between the Craig-Gordon model and experimental results for soil water undergoing evaporation (Mathieu and Bariac 1996, Clark and Fritz 1999).

Previous models have assumed that leaf water is well-mixed and isotopically uniform. The enrichment of leaf water above stem water $\left(\Delta_{\mathrm{e}}\right)$ during transpiration was therefore described by an equation using the same principles developed by Craig and Gordon (1965):

$$
\Delta_{\mathrm{e}}=\varepsilon^{*}+\varepsilon_{\mathrm{k}}+\left(\Delta_{\mathrm{v}}-\varepsilon_{\mathrm{k}}\right) \mathrm{e}_{a} / \mathrm{e}_{i}
$$

where $\varepsilon^{*}$ is the proportional depression of water vapour pressure over heavy isotopes compared with the vapour pressure over light isotopes; $\varepsilon_{\mathrm{k}}$ is the kinetic fractionation as water vapour moves through the stomata and leaf boundary layer; and $\Delta_{\mathrm{V}}$ is the isotope composition of atmospheric water vapour relative to plant stem water. The parameter $\mathrm{e}$ is the water vapor pressure and subscripts $a$ and $i$ refer to bulk air and intercellular air spaces, respectively. It can be seen that the vapor pressure gradient $\left(\mathrm{e}_{a} / \mathrm{e}_{i}\right)$, which is directly related to relative humidity, is an important component dictating leaf water isotopic enrichment.

However, many studies have reported that the observed isotopic composition of bulk leaf water is usually less enriched than that predicted by the above equation (Yakir et al. 1990, Flanagan and Ehleringer 1991, Flanagan et al. 1991, Yakir et al. 1993, Yakir and Sternberg 2000). The reasons for these discrepancies are especially affected by life form and plant hydraulic properties (Lai et al. 2008) which are related to (i) nonuniform stomatal closure that promote different enrichments between cells adjacent to open and closed stomata (Flanagan et al. 1991, Luo and Sternberg 1992) and (ii) different pools of water within leaves (apoplastic and symplastic water as well as water in veins) some of which may not be exposed directly to evaporative conditions (Yakir et al. 1989, 1990, 1993, Flanagan et al. 1991, Yakir and Sternberg 2000). The cell wall surfaces, which are exposed to evaporation, correspond to part of the apoplastic water fraction that have its isotopic composition influenced by environmental conditions, showing diurnal isotope ratio fluctuations (Yakir et al. 1989, 1990). This pool of water does not completely mix with bulk leaf water (Yakir and Sternberg 2000). The symplastic water is not completely exposed to evaporation but may be affected by the isotopically enriched apoplastic water (Yakir and Sternberg 2000). The third pool consists of the water in the veins showing a high proportion of unfractionated water that reflects the water absorbed from roots (Flanagan and Ehleringer 1991, Luo and Sternberg 1992).

Farquhar and Lloyd (1993) modeled leaf water isotopic composition by invoking the Péclet effect, which explained the above discrepancies and other observed characteristics of leaf water isotopic enrichment. The Péclet effect is quantified as $\rho$ and is the result of the mixing between the convective flux of unfractionated water and the back diffusion of isotopically enriched water from the evaporating sites into the leaf, represented by the equation:

$$
\rho=T L / C D \text {. }
$$

The molar concentration of water $\left(5.56 \times 10^{4}\right.$ mol. $\mathrm{m}^{-3}$ ) is represented by $C, D$ is the diffusivity of DHO and $\mathrm{H}_{2}{ }^{18} \mathrm{O}$ through water, $T$ is the rate of transpiration rate and $L$ is the effective length in the leaf that water has to travel from the xylem to 
the evaporative site. This parameter is a product of the constant of proportionality, $\mathrm{k}$, and the distance from the evaporating surfaces to the leaf veins, $L$ (Barbour et al. 2000, Barbour and Farquhar 2003). The isotopic enrichment of bulk leaf water relative to stem water $\left(\Delta_{\mathrm{L}}\right)$ is integrated over this mixing gradient and given by:

$$
\Delta_{\mathrm{L}}=\Delta_{\mathrm{e}}\left(1-\mathrm{e}^{-\rho}\right) / \rho
$$

Thus, according to this model, the greater the Péclet number, the less enriched the leaf water will be relative to stem water. Likewise, leaf water enrichment approaches the values of $\Delta_{\mathrm{e}}$ predicted by equation 1 as the Péclet number decreases. The Péclet number in turn is a function of different leaf morpho-physiological characteristics which might affect the two components of the Péclet values: transpiration rate and the path length. Although the contribution of day- and nighttime transpiration to equilibrium between leaf water and atmospheric water vapor have been described (Lai et al. 2008), for path length, however, few studies have investigated to what degree leaf morpho-physiological traits could affect leaf water isotopic enrichment (Kahmen et al. 2008, Kahmen et al. 2009). In fact, it has been observed that leaf hydraulic properties related to mesophyll features are directly related to changes in $L$ (Ferrio et al. 2009). This later study indicates, to some extent, the role of leaf morpho-physiological traits in leaf water isotopic enrichment, which may be relevant in the improvement of models describing leaf isotopic enrichment.

Here, we evaluate in which way leaf morphophysiological traits could affect leaf water isotopic enrichment in six restinga woody species. For this purpose, we choose leaf traits commonly used in ecophysiological studies, such as leaf mass per area, leaf thickness, leaf density and leaf physiological traits obtained from pressure-volume curves that describe performance of species in terms of water use (Rosado and de Mattos 2010). We collected these data in a coastal vegetation of Brazil known as restinga, where the substrate is formed by coastal sandy barriers from marine sources; characterized by low water retention and poor nutrients and organic matter. Although restinga species possess functional traits to deal with low water and nutrient availability, variations in leaf morphological traits among species (Rosado and de Mattos 2010) might lead to distinct species responses to fluctuations in resources' availability and consequently in the isotopic identity of leaf water.

\section{MATERIALS AND METHODS}

\section{STUDY AREA}

Measurements were done in the Restinga of Jurubatiba National Park covering 14,140 hectares and located north of the state of Rio de Janeiro, Brazil $\left(22^{\circ}\right.$ and $22^{\circ} 23^{\prime} \mathrm{S}$ and $41^{\circ} 15^{\prime}$ and $\left.41^{\circ} 35^{\prime} \mathrm{W}\right)$. The mean annual precipitation, between 1,100 to $1,300 \mathrm{~mm}$, is seasonal with the month average minimum in winter of $41 \mathrm{~mm}$ and month average maximum in summer of $189 \mathrm{~mm}$. The mean annual temperature is $22.6^{\circ} \mathrm{C}$ (Araujo et al. 1998). The flora of the Restinga of Jurubatiba is derived from the Atlantic rain forest and has eleven different vegetation assemblages with different species and life forms (Araujo et al. 2004). The plant assemblage known as the open Clusia scrub is the most common assemblage. It represents $45 \%$ of park area (Araujo et al. 2004) and is the focus of this study. The Clusia scrub assemblage is characterized by areas of bare sand and vegetation thickets having woody shrubs with broad leaves and the $\mathrm{C}_{3}$ photosynthetic pathway with the exception of Clusia hilariana (Clusiaceae). The most common species found in these thickets (Araujo et al. 2004) and the ones studied here are: Protium icicariba (DC.) Marchand (Burseraceae), Byrsonima sericea DC. (Malpighiaceae), Myrsine parvifolia A.DC (Myristicaceae), Erythroxylum ovalifolium Peyr. (Erythroxylaceae), Eugenia umbelliflora Berg (Myrtaceae) and Maytenus obtusifolia Mart. (Celastraceae). 
Measurement of Leaf Mass Per Area, Succulence,

THICKNESS AND DENSITY

We used the mean values from the dataset obtained by Rosado and de Mattos (2007) from nine measurements made from February of 2003 to August of 2005 (three per year) for the above species at this site. To measure the above parameters, ten leaves from separate individuals of each species were collected on the north side of their respective canopies. A leaf disc from each leaf was taken with a cork borer for the determination of leaf attributes. Each disc was immersed in water for a period of 24 hours for the measurement of saturated mass $\left(\mathrm{FM}_{\mathrm{sat}}, \mathrm{g}\right)$. After leaf discs were fully hydrated, each disc had their thickness $(\mathrm{TH}, \mathrm{mm})$ measured with a digital caliper and was then oven-dried for 72 hours for determination of dry mass (DM, g). Leaf mass per area (LMA, g. $\mathrm{m}^{-2}$ ) was calculated by dividing disc mass by its area (A) while the capacity of water storage in the leaf known as the succulence index (SUC, g. $\mathrm{m}^{-2}$ ) was measured as: (Fmsat - DM)/A. The foliar density (DEN, $\mathrm{mm} \cdot \mathrm{mm}^{-3}$ ) was estimated following the formula: LMA $=$ TH $*$ DEN (Witkowski and Lamont 1991).

\section{RELATIVE WATER CONTENT OF APOPLAST ( RWC $_{\text {APOP }}$ )}

During the wet season of 2005 , one sun-exposed branch from each of seven individuals with mature leaves was cut from each species and used to measure the pressure-volume parameters. The base of each branch was cut under water in the laboratory and placed in a water recipient, covered with a humidified plastic bag and equilibrated in a dark room for about 12 hours. After initial measurements of water potential (PMS Instruments, Corvallis, OR, USA) and fresh mass, branches were dry on the bench and water potential and branch mass were periodically measured during dehydration (Tyree and Hammel 1972). The $\mathrm{RWC}_{\text {apop }}$ was obtained from the pressure-volume curves of each species based on approximately 20 measurements. P-V curves have a non-linear and a linear part (Boyer 1995). We determined the slope and intercept of a linear regression on the linear portion of the inverse balance pressure vs. fresh weight of the branch plot. The $\mathrm{RWC}_{\text {apop }}$ was obtained by dividing the intercept by the slope of the linear regression.

STABLE ISOTOPES ANALYSIS

\section{Oxygen and Hydrogen Isotope Analyses}

We collected samples from four individuals of each species on November 2005 and January 2006. Despite the observed variation in isotopic composition in leaves along the day (Lai et al. 2008), we collected the samples during the later morning for all species where we expect the leaves were transpiring and probably reaching a steady state. Although these months are considered as "wet" season, the January 2006 samples were collected at the end of a three week rainless period (dry spell). Dry spells on the restingas are common, which may decrease the water availability even during the wet season due to the low water retention of sandy soils (Cavalin and de Mattos 2007). For each individual we sampled a well suberized stem (up to $4 \mathrm{~cm}$ in length and up to $1 \mathrm{~cm}$ in diameter) and one of the sun exposed north facing leaves, which was subsequently deveined. Eight soil samples were also collected $10 \mathrm{~cm}$ from the soil surface in November 2005 and January 2006. Soil, stems and deveined leaves were sealed in Vacutainer ${ }^{\odot}$ tubes, further sealed with Parafilm ${ }^{\odot}$ and kept frozen until water distillation (Moreira et al. 2000). After distillation, oxygen and hydrogen isotope ratios of water were measured by equilibration on an Isoprime $^{\circledR}$ Isotope Ratio Mass Spectrometer connected to a Multiflow $^{\odot}$ system (Elementar, Hanau, Germany) with the respective precision of $\pm 0.1 \%$ and $\pm 2.0 \%$. Oxygen and hydrogen isotope ratios are reported here as $\delta^{18} \mathrm{O}$, and $\delta \mathrm{D}$ respectively and calculated as:

$$
\delta^{18} \mathrm{O} \text { or } \delta \mathrm{D}=\left(\left(\mathrm{R}_{\text {sample }} / \mathrm{R}_{\text {Smow }}\right)-1\right) \times 1,000,
$$


in which $\mathrm{R}_{\text {sample }}$ and $\mathrm{R}_{\text {SMOW }}$ represent the heavy (to light isotope ratio of the sample and the standard respectively. The standard for water isotope ratios used here is Vienna standard mean ocean water (vSMOW).

We calculated the isotopic leaf water enrichment relative to stem water $\left(\Delta_{L}\right)$ for both hydrogen and oxygen isotopes according to the following equation:

2)

$$
\Delta_{\mathrm{L}}=\left[\frac{\left(\frac{\delta_{\mathrm{L}}}{1,000}+1\right)}{\left(\frac{\delta_{\mathrm{S}}}{1,000}+1\right)}-1\right] \times 1,000,
$$

in which $\delta_{\mathrm{L}}$ and $\delta_{\mathrm{S}}$ are either the $\delta^{18} \mathrm{O}$ or $\delta \mathrm{D}$ values of leaf and stem water respectively.

\section{RESULTS}

The $\delta \mathrm{D}$ and $\delta^{18} \mathrm{O}$ values of stem water for November 2005 and January 2006 were close to the Global Meteoric Water Line (GMWL) compared with those of soil water (Fig. 1). However, the isotopic values of the January samples were more depleted than those of November (Fig. 1 and Table I). When stem and leaf water $\delta \mathrm{D}$ values are plotted against the respective $\delta^{18} \mathrm{O}$ values a highly significant linear relationship was described with a slope lower than that of the GMWL (a slope $=2.62, \mathrm{R}^{2}=0.79$ for November and a slope $=3.53, \mathrm{R}^{2}=0.91$ for January). November and January Isotopic ratios of soil water were between those of leaf and stem water values with November samples being more enriched than those of January (Fig. 1).

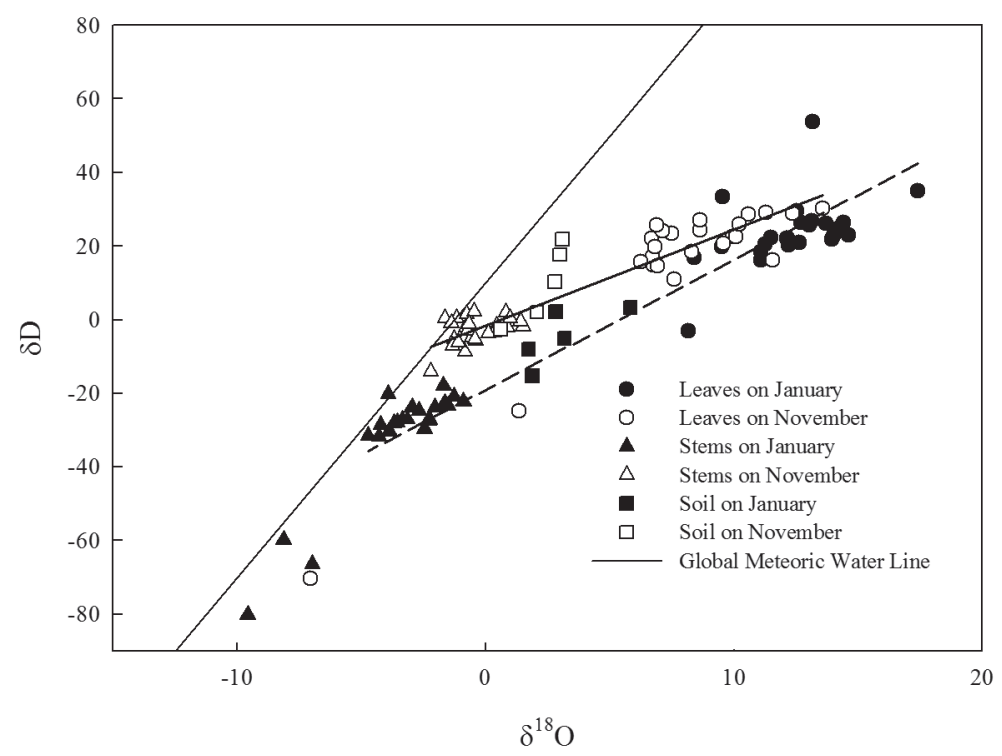

Figure 1 - Hydrogen isotope ratios of leaf, stem and soil water versus the respective oxygen isotope ratios of each species and soil samples for November of $2005\left(\mathrm{y}=2.62-1.576 \mathrm{x} ; \mathrm{R}^{2}=0.79\right)$ and January of $2006(\mathrm{y}=3.53-19.03 \mathrm{x}$; $\left.\mathrm{R}^{2}=0.91\right)$ compared to the meteoric relationship between $\delta^{18} \mathrm{O}$ and $\delta{ }^{2} \mathrm{H}$ of precipitation $\left(\delta^{2} \mathrm{H}=8.13 \delta 18 \mathrm{O}+10.8\right)$.

Erythroxilum ovalifolium and Byrsonima sericea had significantly higher $\delta^{18} \mathrm{O}$ values of stem water compared to those of the other species during the wet November collection (Table I). No significant difference in the isotopic ratios of stem water between species during the dry period sampling in January was observed. The range of dry season stem water isotopic values, however, was greater than those observed during the wet sampling in November. Leaf water oxygen and 
hydrogen isotopic enrichment $\left(\Delta_{\mathrm{L}}\right)$ of Protium icicariba, Eugenia umbelliflora and Maytenus obtusifolia was higher than the other species during the wet November sampling (Table I), but no significant difference was observed for the dry January samples.

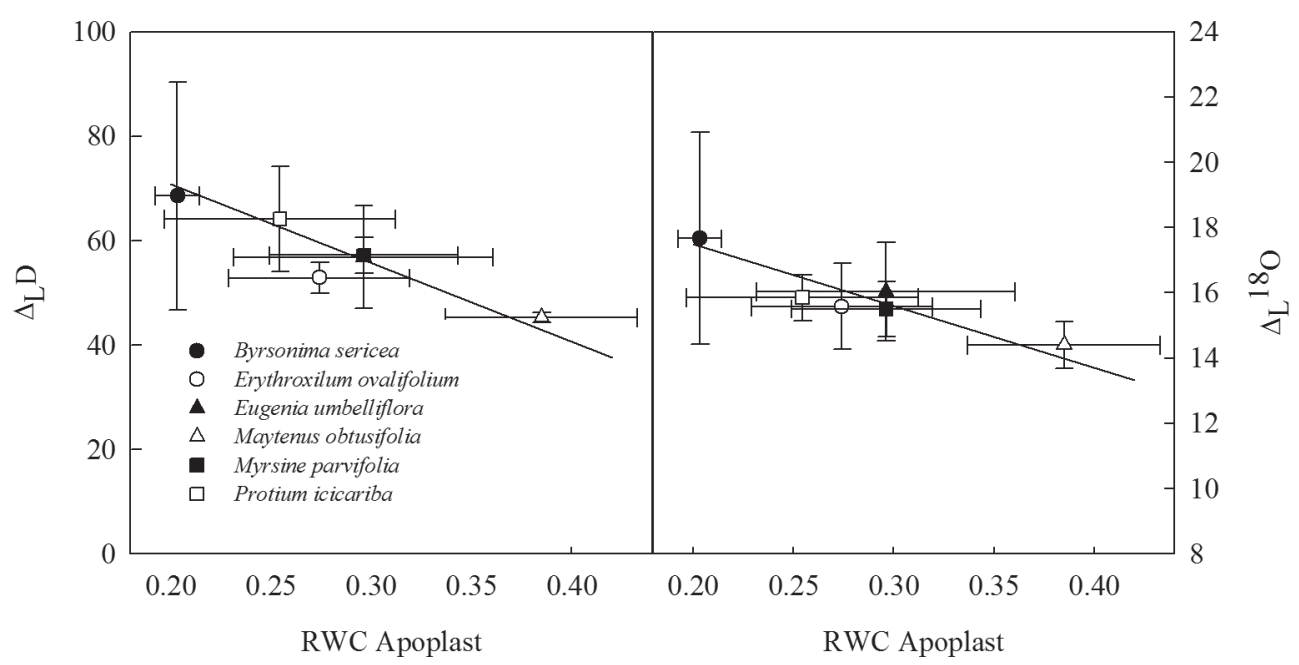

Figure 2 - Negative relationship between Relative Apoplastic Water Content $\left(\mathrm{RWC}_{\text {apop }}\right)$ and $\Delta_{\mathrm{L}}{ }^{18} \mathrm{O}_{\mathrm{Jan}}$ and $\Delta_{\mathrm{L}} \mathrm{D}_{\text {Jan }}\left(\mathrm{y}=93.80+127.59 \mathrm{x} ; \mathrm{R}^{2}=0.86\right.$ and $\mathrm{y}=20.47+16.25 \mathrm{x} ; \mathrm{R}^{2}=0.84$, respectively $)$. Without Byrsonima $\left(\Delta_{\mathrm{L}}{ }^{18} \mathrm{O}_{\text {Jan }} \mathrm{R}^{2}=0.72 ; \mathrm{P}<0.04 ; \mathrm{y}=18.89+11.35 \mathrm{x}\right) ; \Delta_{\mathrm{L}} \mathrm{D}_{\text {Jan }}\left(\mathrm{R}^{2}=0.68 ; \mathrm{p}=0.05 ; \mathrm{y}=91.53+120.51 \mathrm{x}\right)$.

$\mathrm{RWC}_{\text {apop }}$ varied from 0.203 to 0.590 among the six species studied (Fig. 2) and it was not related to any of the other measured morphological traits (Table II). The January average $\Delta_{\mathrm{L}}{ }^{18} \mathrm{O}$ and $\Delta_{\mathrm{L}} \mathrm{D}$ values were negatively correlated only with $\mathrm{RWC}_{\text {apop }}$ at a highly significant level $\left(\mathrm{R}^{2}=0.84\right.$, $\mathrm{P}<0.01$ and $\mathrm{R}^{2}=0.86, \mathrm{P}<0.01$ respectively, Fig. 2; Table II) and the relationship remained significant even when Byrsonima (the outlier value) was removed $\left(\mathrm{R}^{2}=0.72 ; \mathrm{P}<0.04\right.$ and $\mathrm{R}^{2}=0.68 ; \mathrm{P}=0.05$, respectively). The leaf water isotopic enrichment $\left(\Delta_{\mathrm{L}}{ }^{18} \mathrm{O}\right.$ and $\left.\Delta_{\mathrm{L}} \mathrm{D}\right)$ for the November sample did not correlate with any of the leaf traits measured here.

\section{DISCUSSION}

According to the Craig-Gordon model soil water becomes isotopically enriched during periods of intense evaporation (Clark and Fritz 1999, Yakir and Sternberg 2000). In both months, the isotopic ratios of soil water were disproportionally enriched in ${ }^{18} \mathrm{O}$ relative to the GMWL indicating evaporative effects near the soil surface. The isotopic composition of stem water which were closer to the meteoric water line are probably indicative of water use deeper in the soil profile and similar to the average isotopic composition of rain water at the time of sampling. If so, then the average $\delta^{18} \mathrm{O}$ and $\delta \mathrm{D}$ value of rainfall during the month of November was greater than that occurring during January. It was not possible, however, to determine at which depth of the soil profile the species absorbed water, because we did not collect soil samples at different depth for isotopic analyses of soil water

The range of average $\delta^{18} \mathrm{O}$ values of stem water for each species during January (-4.83 to -1.75$)$ was greater than that observed for the November samples $(-1.23$ to +0.92$)$. This may be caused not only by a greater variability in water source between species, but also between individuals of the same species during drought periods. More variable water sourcing by plants in a coastal sand 
TABLE I

Leaf water oxygen and hydrogen isotopic enrichment $(\Delta \mathrm{L})$ and hydrogen and oxygen isotope ratios of plant stem water $(\delta)$ for each species for November of 2005 and January of 2006. Different letters for each month in each variable indicating significant differences among species $(\mathbf{p}<\mathbf{0 . 0 5})$ and asterisks indicating significant differences in each species for each variable between months $(p<0.05)$.

\begin{tabular}{|c|c|c|c|c|c|c|c|c|}
\hline \multirow{2}{*}{ Species } & \multicolumn{2}{|c|}{$\Delta_{\mathrm{L}}^{18} \mathrm{O}$} & \multicolumn{2}{|c|}{$\Delta_{\mathrm{L}} \mathrm{D}$} & \multicolumn{2}{|c|}{$\delta^{18} \mathrm{O}$ Stem } & \multicolumn{2}{|c|}{$\delta \mathrm{D}$ Stem } \\
\hline & Jan & Nov & Jan & Nov & Jan & Nov & Jan & Nov \\
\hline \multirow{2}{*}{ Byrsonima sericea } & $17.66 \pm$ & $5.84 \pm$ & $68.56 \pm$ & $17.99 \pm$ & $-4.83 \pm$ & $0.92 \pm$ & $-47.70 \pm$ & $-0.86 \pm$ \\
\hline & $3.25 \mathrm{a}^{*}$ & $0.24 \mathrm{ab}$ & $21.79 \mathrm{a}$ & $2.06 \mathrm{a}$ & $2.06 \mathrm{a}$ & $0.22 b$ & $15.03 \mathrm{a}^{*}$ & $0.99 \mathrm{a}$ \\
\hline \multirow{2}{*}{ Erythroxylum ovalifolium } & $15.58 \pm$ & $5.22 \pm$ & $52.86 \pm$ & $11.52 \pm$ & $-1.75 \pm$ & $0.71 \pm$ & $-24.66 \pm$ & $-1.80 \pm$ \\
\hline & $1.32 \mathrm{a}^{*}$ & $1.79 \mathrm{a}$ & $2.93 \mathrm{a}^{*}$ & $12.04 \mathrm{a}$ & $0.33 \mathrm{a}^{*}$ & $0.30 \mathrm{~b}$ & $1.74 \mathrm{a}^{*}$ & $1.02 \mathrm{a}$ \\
\hline \multirow{2}{*}{ Eugenia umbelliflora } & $16.04 \pm$ & $10.94 \pm$ & $56.81 \pm$ & $29.29 \pm$ & $-3.76 \pm$ & $-0.76 \pm$ & $-32.18 \pm$ & $-6.12 \pm$ \\
\hline & $1.52 \mathrm{a}^{*}$ & $0.80 \mathrm{c}$ & $9.81 \mathrm{a}^{*}$ & $1.48 \mathrm{a}$ & $1.48 \mathrm{a}$ & $0.19 \mathrm{a}$ & $9.39 \mathrm{a}^{*}$ & $0.90 \mathrm{a}$ \\
\hline \multirow{2}{*}{ Maytenus obtusifolia } & $14.40 \pm$ & $10.51 \pm$ & $45.25 \pm$ & $25.28 \pm$ & $-3.66 \pm$ & $-1.23 \pm$ & $-25.72 \pm$ & $-2.09 \pm$ \\
\hline & $0.71 \mathrm{a}^{*}$ & $0.57 b c$ & $0.91 \mathrm{a}^{*}$ & $2.62 \mathrm{a}$ & $0.25 \mathrm{a}^{*}$ & $0.18 \mathrm{a}$ & $1.90 \mathrm{a}^{*}$ & $1.72 \mathrm{a}$ \\
\hline \multirow{2}{*}{ Myrsine parvifolia } & $15.50 \pm$ & $4.66 \pm$ & $57.17 \pm$ & $5.10 \pm$ & $-4.10 \pm$ & $-1.21 \pm$ & $-30.32 \pm$ & $-5.41 \pm$ \\
\hline & $0.84 \mathrm{a}^{*}$ & $3.17 \mathrm{abc}$ & $3.40 \mathrm{a}^{*}$ & $20.73 a$ & $0.25 \mathrm{a}^{*}$ & $0.34 \mathrm{a}$ & $0.88 \mathrm{a}^{*}$ & $3.28 \mathrm{a}$ \\
\hline \multirow{2}{*}{ Protium icicariba } & $15.85 \pm$ & $12.24 \pm$ & $64.09 \pm$ & $25.33 \pm$ & $-2.45 \pm$ & $-0.74 \pm$ & $-26.76 \pm$ & $-1.28 \pm$ \\
\hline & $0.70 a^{*}$ & $0.99 \mathrm{c}$ & $10.09 \mathrm{a}^{*}$ & $4.62 \mathrm{a}$ & $0.53 \mathrm{a}^{*}$ & $0.22 \mathrm{a}$ & $1.06 \mathrm{a}^{*}$ & $1.50 \mathrm{a}$ \\
\hline
\end{tabular}

TABLE II

Correlation matrix between isotopic ratios of stem water and leaf water isotopic enrichment versus different leaf traits. Bold values are statistically significant $(\mathbf{p}<0.05)$.

\begin{tabular}{ccccccccc}
\hline Leaf Traits & $\delta \mathrm{D}_{\text {Stem Jan }}$ & $\delta_{\mathrm{D}_{\text {Stem Nov }}}$ & $\delta^{18} \mathrm{O}_{\text {Stem Jan }}$ & $\delta^{18} \mathrm{O}_{\text {Stem Nov }}$ & $\Delta_{\mathrm{L}} \mathrm{D}_{\text {Jan }}$ & $\Delta_{\mathrm{L}} \mathrm{D}_{\text {Nov }}$ & $\Delta_{\mathrm{L}}{ }^{18} \mathrm{O}_{\text {Jan }}$ & $\Delta_{\mathrm{L}}{ }^{18} \mathrm{O}_{\mathrm{Nov}}$ \\
\hline Leaf Mass per Area & -0.16 & -0.58 & -0.66 & -0.5 & -0.41 & 0.33 & -0.23 & 0.19 \\
Leaf Succulence & 0.0 & -0.76 & -0.59 & -0.6 & -0.48 & -0.09 & -0.35 & -0.11 \\
Leaf Thickness & -0.09 & -0.76 & -0.64 & -0.52 & -0.4 & -0.16 & -0.26 & -0.2 \\
Leaf Density & -0.11 & 0.54 & 0.11 & 0.1 & 0.25 & 0.85 & 0.18 & 0.78 \\
$\begin{array}{c}\text { Relative Apoplastic } \\
\text { Water Content }\end{array}$ & 0.66 & -0.31 & 0.09 & -0.72 & $\mathbf{- 0 . 9 3}$ & 0.2 & $\mathbf{- 0 . 9 2}$ & 0.32 \\
\hline
\end{tabular}

dune community under salt water impact was previously observed by Greaver and Sternberg (2006), where plants in the seaward side of sandy coastal plains did not show significantly different water source relative to landward plants based on isotopic composition of stem water. Seaward plants, however, showed greater variance in the isotopic composition of stem water than landward plants, indicative of a more variable water source for seaward coastal dune plants.

Despite the fact that the January water source was isotopically lighter than those of November, factors such as lower relative humidity $(\mathrm{RH})$ or a different transpiration regime could have caused the isotopic enrichment of leaf water of the January samples to be greater than those of November (Yakir and Sternberg 2000). Our results at the species level showed absence of significant differences in leaf water isotopic enrichment among species over the long dry spell of January, but not during favorable water availability in November. Recently, a trait-based approach in restinga indicated that temporal variation in water availability may predispose plants to water shortage during rainless days what may explain the convergence of leaf water isotopic fractionation during the dry spell (Rosado and de Mattos 2010). 
Restinga plants show high values of leaf water potential at the turgor loss point, less negative osmotic pressure and most species have indications of chronic photoinhibition during the dry season. In addition, some species have a lower amount of leafarea available for transpiration during the dry season (Rosado and de Mattos 2010). In terms of leaf morphological traits, Rosado and de Mattos (2007) also reported in the same restinga species, a trend of highest values of LMA, SUC, TH and DEN in dry months during three years of study suggesting convergent responses to deal with temporal heterogeneity of water availability. Additionally, in a broad scale, the study of Huxman et al. (2004) also observed that despite differences across biomes in annual precipitation, physiognomy and climatic history, rain use efficiency (i.e., the ratio of aboveground net primary production to precipitation) converged during years when water was the most liming factor. Thus, in spite of differential ability of plants to cope with water shortage, during periods of strong water limitation, plants may show convergence of responses, which might be more related to a universal limit of plant survival under stressful conditions.

We observed that the greater the $\mathrm{RWC}_{\text {apop }}$, the lower the average $\Delta_{\mathrm{L}}{ }^{18} \mathrm{O}$ and $\Delta_{\mathrm{L}} \mathrm{D}$ of leaf water during the dry spell. According to Steudle et al. (1993), the water movement within leaves can occur simultaneously in three different pathways: (i) apoplastic flow through cell walls or cell to cell movement; (ii) via aquaporins; and (iii) plasmodesmata. Barbour et al. (2000) pointed out the importance of the increases in the effective length $(L)$ to produce significant Péclet effect because of increases in the tortuosity in the water movement from the vein to the leaf evaporative surface. Barbour and Farquhar (2003) using wheat leaf as a model, estimated $L$ for apoplastic pathway, between 9 and $15 \mathrm{~mm}$, and for plasmodesmata and aquaporin pathway, between 121 and $201 \mathrm{~mm}$ and 9 and $15 \mathrm{~mm}$, respectively. The authors observed that the three pathways of water movement presented different contributions to the enrichment between the vein and the evaporation sites and consequently could create a significant Péclet effect. We suggest that a best test for an important control of the Péclet effect would be the parameter 1-De/D1, where De is Craig-Gordon enrichment and Dl is observed steady-state leaf water enrichment, against the parameter that is presumed to be controlling the Péclet number, which would the $\mathrm{RWC}_{\text {apop}}$.

Although we did not measure leaf transpiration, our results open new perspectives about the leaf traits that could affect $\Delta_{\mathrm{L}}$. Interestingly, despite recent findings demonstrating that traits related to leaf hydraulic conductance are positively related to $L$ (Ferrio et al. 2012), our non-significant relationships between stem and leaf water isotopic enrichment and leaf morphological traits are contrary to these results since leaf hydraulic conductance and mesophyll conductance might be negatively related to such leaf traits like LMA and TH (Aasamaa et al. 2005, Flexas et al. 2008). In fact, in cases where water flow is reduced due to tortuous apoplastic pathway, increases in effective $L$ has been observed (Ferrio et al. 2009, Zhou et al. 2011). As mentioned by Lai et al (2008), $L$ has never been directly measured and the effect of the uncertainties of measurement of $L$ on $\Delta_{\mathrm{L}}$ is unknown. Therefore, we suggest that RWCapop, as proxy for $L$, may perform a conspicuous role, in the movement of water and the tortuosity of the pathway from leaf vein to the evaporative surface.

As discussed previously, bulk leaf water isotopic enrichment is in part a function of the Péclet number, which in turn is a function of transpiration (T) and the effective diffusive length of the leaf $(L)$. Here, we propose that during the relatively wet month of November, transpiration typical of each species is a source of distinction in the leaf water isotopic enrichment. During the dry spell, however, transpiration rates may decrease to a consistently low value between restinga species (L.B. Lignani et al., unpublished data), raising the importance 
of the effective diffusive length as of great source of variability for the bulk leaf water enrichment among species. Contrary to other studies performed in tropical forests where plants are subjected to high environmental heterogeneity (Lai et al. 2008), the $\mathrm{RH}$ and isotope ratios of water vapor cannot explain the variability observed here since during sample collection all plants were exposed to the same RH and vapor pressure deficit (B.H.P. Rosado et al., unpublished data). Supporting this, we observed that during the wet season average leaf water enrichment did not correlate with $\mathrm{RWC}_{\text {apop}}$. Hence, future studies performed in drought prone habitats where transpiration rate is low, should consider the role of $\mathrm{RWC}_{\text {apop }}$ as a proxy for the effective diffusive length of the leaf (L) in isotopic models of leaf water enrichment.

In conclusion, we raised important aspects that will deepen our understanding regarding the mechanisms affecting leaf water enrichment and the diversity of ecophysiological behaviors in restinga plants. We demonstrated that despite differences in isotopic signatures during periods of higher water availability, restinga plants may converge to a similar foliar response during a long dry spell amidst the rainy season. Moreover, during a drought period the average leaf water isotopic enrichment may be determined by anatomical properties of leaves, which are reflected in the $\mathrm{RWC}_{\text {apop. }}$. Therefore, we suggest that $\mathrm{RWC}_{\text {apop }}$ may be an important functional trait to be used as a proxy $L$ in isotopic models explaining leaf water isotopic enrichment.

\section{ACKNOWLEDGMENTS}

We are grateful to P. Cavalin for his help in field work and to G. Cardinot for help us with P-V curves. Sincere thanks go to Maria C. Pinzon, Amartya Saha and Patrick Ellsworth for great help in laboratory and useful discussions. We thank the staff from NUPEM-UFRJ and National Park for logistic support. This study was supported with grants from
Conselho Nacional de Desenvolvimento Científico e Tecnológico (CNPq), Fundação de Amparo à Pesquisa do Estado do Rio de Janeiro (FAPERJ) and the Brazilian Long Term Ecological Research Program (PELD-CNPq) for B.H.P.R. and E.A. de M. and NSF \#0322051 and \#0420553 for L. da S.L.S.

\section{RESUMO}

Durante a transpiração das plantas, moléculas de água com isótopos mais leves de oxigênio e hidrogênio evaporam e se difundem mais rapidamente através dos estômatos do que moléculas com isótopos mais pesados, o que causa enriquecimento isotópico de água em folhas. Embora modelos prévios assumam que a água da folha é bem misturada e isotopicamente uniforme, o fechamento não uniforme dos estômatos, promovendo enriquecimentos diferentes entre as células e diferentes compartimentos de água dentro de folhas, devido às características morfofisiológicas, podem levar a imprecisões dos modelos isotópicos na previsão de enriquecimento da água foliar. Nós avaliamos o papel de atributos morfo-fisiológicos foliares sobre o enriquecimento isotópico da água foliar em espécies arbóreas que ocorrem em planícies arenosas costeiras no Brasil, conhecidas como restingas. Isótopos estáveis de hidrogênio e oxigênio em amostras de solo, ramos e folhas e características foliares foram medidos em seis espécies arbóreas de restinga durante períodos seco e chuvoso. O enriquecimento isotópico de água foliar relativo à água dos ramos foi mais homogêneo entre as espécies durante a seca, em contraste com o período chuvoso, sugerindo respostas convergentes para lidar com a heterogeneidade temporal na disponibilidade de água. A média de enriquecimento isotópico de água foliar relativo à água dos ramos durante o período de seca foi altamente correlacionada com o conteúdo relativo de água apoplasmática. Nós discutimos estes resultados no contexto de modelos atuais de enriquecimento isotópico de água foliar como uma função do efeito Péclet. Sugerimos que estudos futuros devem incluir o conteúdo relativo de água apoplasmático em modelos isotópicos.

Palavras-chave: enriquecimento isotópico foliar, efeito Péclet, restinga, atributos morfofisiológicos. 


\section{REFERENCES}

AASAMAA K, NIINEMETS Ü AND SÕBER A. 2005. Leaf hydraulic conductance in relation to anatomical and functional traits during Populus tremula leaf ontogeny. Tree Physiol 25: 1409-1418.

Araujo DSD, PEREIRA MCA AND Pimentel M. 2004. Flora e estrutura de comunidades na Restinga de Jurubatiba Síntese dos conhecimentos com enfoque especial para a Formação Aberta de Clusia. In: ROCHA CFD, ESTEVES FA and SCARANO FR (Eds), Pesquisas de longa duração na restinga de Jurubatiba Ecologia, história natural e conservação, RiMa Editora, São Carlos, Brasil, p. 59-76.

ARAUJO DSD, SCARANO FR, SÁ CFC, KURTZ BC, ZALUAR HLT, MONTEZUMA RCM AND OLIVEIRA RC. 1998. Comunidades vegetais do Parque Nacional da Restinga de Jurubatiba. In: ESTEVES FA(Ed), Ecologia das Lagoas Costeiras do Parque Nacional da Restinga de Jurubatiba e do Município de Macaé (RJ), NUPEM-UFRJ, Rio de Janeiro, Brasil, p. 39-62.

BARbour MM AND FARQuHAR GD. 2003. Do pathways of water movement and leaf anatomical dimensions allow development of gradients in $\mathrm{H}_{2}{ }^{18} \mathrm{O}$ between veins and the sites of evaporation within leaves? Plant Cell Environ 27: 107-121.

BARbour MM, SCHURr U, HENRY BK, WONG SC AND FARQUHAR GD. 2000. Variation in the oxygen isotope ratio of phloem sap sucrose from Castor Bean Evidence in support of the Péclet Effect. Plant Physiol 123: 671-679.

BOYER JS. 1995. Measuring the water status of plant and soils Academic Press, San Diego, California, USA, 178 p.

CAVAlin PO AND DE Mattos EA. 2007. Spatio-temporal variation of photosynthetic pigments in the CAM tree Clusia hilariana Schlechtendal associated with dry spells during the rainy season in southeastern Brazil. Trees: Structure and Function 21: 671-675.

CLARK I AND FRITZ P. 1999. Environmental Isotopes in Hydrogeology. Lewis Publishers, Boca Raton, Florida, USA, $312 \mathrm{p}$.

CRAIG H AND GORDON LI. 1965. Deuterium and oxygen-18 variations in the ocean and the marine atmosphere. In: TONGIORGI E (Ed), Proceedings of the conference on stable isotopes in oceanographic studies and paleotemperatures, Laboratory of Geology and Nuclear Science, Pisa, Italy, p. 9-130.

Dawson TE, Mambelli S, Plamboeck AH, Templer PH AND TU KP. 2002. Stable isotopes in plant ecology. Ann Rev Ecol Syst 33: 507-559.

FARQUHAR GD AND LLOYD J. 1993. Carbon and oxygen isotope effects in the exchange of carbon dioxide between terrestrial plants and the. In: EHLERINGER JR, HALLE AE and FARQUHAR GD (Eds), Stable isotopes and Plant Carbon Relations, Academic Press, San Diego, CA, USA, p. 47-70.

FERrio JP, CUNTZ M, OfFERMANN C, SIEGWOLF R, SAURER M AND GESSLER A. 2009. Effect of water availability on leaf water isotopic enrichment in beech seedlings shows limitations of current fractionation models. Plant Cell Environ 32: 1285-1296.
FERrio JP, POU A, FloreZ-SARASA I, GESSLER A, KoDAMA N FLEXAS J AND RIBAS-CARBÓ M. 2012. The Péclet effect on leaf water enrichment correlates with leaf hydraulic conductance and mesophyll conductance for $\mathrm{CO}_{2}$. Plant Cell Environ 35: 611-625.

FLANAGAN LB. 1993. Environmental and biological influences on the stable oxygen and hydrogen isotopic composition of leaf water. In: EHLERINGER JR, HALLE AE and FARQUHAR GD (Eds), Stable isotopes and Plant Carbon Relations, Academic Press, San Diego, CA, USA, p. 71-90.

FLANAGAN LB, COMSTOCK JP AND EHLERINGER JR. 1991. Comparison of modeled and observed environmental influences on the stable oxygen and hydrogen isotope composition of leaf water in Phaseolus vulgaris L. Plant Physiol 96: 588-596.

FLANAGAN LB AND EHLERINGER JR. 1991. Stable isotope composition of stem and leaf water: applications to the study of plant water use. Funct Ecol 5: 270-277.

FleXAs J, RiBAs-CARBó M, DiAZ-ESPEJO A, GALMÉS J AND MEdRANO H. 2008. Mesophyll conductance to CO2: current knowledge and future prospects. Plant Cell Environ 31: 602-621.

GREAVER TL AND STERNBERG LSL. 2006. Linking marine resources to ecotonal shifts of water uptake by terrestrial dune vegetation. Ecology 87: 2389-2396.

HuXMAN TE ET AL. 2004. Convergence across biomes to a common rain-use efficiency. Nature 429: 651-654.

KAHMEN A, Simonin K, TU K, GOLDSMITH GR AND DAWSON TE. 2009. The influence of species and growing conditions on the 18-O enrichment of leaf water and its impact on 'effective path length'. New Phytol 184: 619-630.

Kahmen A, Simonin K, Tu KP, Merchant A, Callister A, SIEGWOLF R, DAWSON TE AND ARNDT SK. 2008. Effects of environmental parameters, leaf physiological properties and leaf water relations on leaf water $\delta^{18} \mathrm{O}$ enrichment in different Eucalyptus species. Plant Cell Environ 31: 738-751.

LAI CT, OMETto JPHB, Berry JA, MARtinelli LA, DOMINGUES TF AND EHLERINGER JR. 2008. Life formspecific variations in leaf water oxygen-18 enrichment in Amazonian vegetation. Oecologia 157: 197-210.

LUO YH AND STERNBERG LSL. 1992. Spatial D/H heterogeneity of leaf water. Plant Physiol 99: 348-350.

MATHIEU R AND BARIAC T. 1996. An isotopic study $\left({ }^{2} \mathrm{H}\right.$ and ${ }^{18} \mathrm{O}$ ) of water movement in clayey soils under a semir-arid climate. Water Resour Res 32: 779-789.

Moreira MZ, SternBerg LSL AND NePSTAD DC. 2000 Vertical patterns of soil water uptake by plants in a primary forest and an abandoned pasture in the eastern Amazon: an isotopic approach. Plant Soil 222: 95-107.

RODEN JS AND EHLERINGER JR. 1999. Observations of Hydrogen and Oxygen isotopes in leaf water confirm the Craig-Gordon model under wide-ranging environmental conditions Plant Physiol 120: 1165-1173.

RODEN JS AND EHLERINGER JR. 2000. Hydrogen and oxygen isotope ratios of tree ring cellulose for field-grown riparian trees. Oecologia 123: 481-489. 
RosAdo BHP AND DE MATTOS EA. 2007. Variação temporal de características morfológicas de folhas em dez espécies do Parque Nacional da Restinga de Jurubatiba. Acta Bot Bras 21: 741-752.

RosAdo BHP AND DE MATTOS EA. 2010. Interspecific variation of functional traits in a CAM-tree dominated sandy coastal plain. J Veg Sci 21: 43-54.

Steudle E, Murrman M AND Peterson CA. 1993. Transport of water solutes across maize roots modified by puncturing the endodermis Further evidence for the composite transport model of the root. Plant Physiol 103: 335-349.

Tyree M And Hammel HT. 1972. The measurements of the turgor pressure and the water relations of plants by the pressure-bomb technique. J Exp Bot 23: 267-282.

YAKIR D, BERRY JA, GILES L AND OSMOND B. 1993. The ${ }^{18} \mathrm{O}$ of water in the metabolic compartment of transpiring leaves. In: EHLERINGER JR, HALLE AE AND FARQUHAR GD (Eds), Stable isotopes and Plant Carbon Relations, Academic Press, San Diego, CA, USA, p. 529-540.

YAKIR D, DENIRO MJ AND GAT JR. 1990. Natural deuterium and oxygen-18 enrichment in leaf water of cotton plants grown under wet and dry conditions: evidence for water compartmentation and its dynamics. Plant Cell Environ 13: $49-56$.
YAKIR D, DENIRO MJ AND RUNDEL P. 1989. Isotopic inhomogeneity of leaf water: Evidence and implications for the use of isotopic signals transduced by plants. Geochim Cosmochim Ac 53: 2769-2773.

YAKIR D AND STERnBERG LSL. 2000. The use of stable isotopes to study ecosystem gas exchange. Oecologia 123: 297-311.

WITKOWSKI ETF AND LAMONT BB. 1991. Leaf specific mass confounds leaf density and thickness. Oecologia 88: 486-493.

Zhou Y, Grice K, ChiKaraishi Y, Stuart-Williams H, FARQUHAR GD AND OHKOUCHI N. 2011. Temperature effect on leaf water deuterium enrichment and isotopic fractionation during leaf lipid biosynthesis: results from controlled growth of $\mathrm{C}_{3}$ and $\mathrm{C}_{4}$ land plants. Phytochemistry 72: $207-213$. 